\title{
The effectiveness of frog VLE implementation: students' perspective
}

\author{
Rogayah Abdul Majid, Juhaida Che Hasim \\ Faculty of Computing and Mathematical Sciences, Universiti Tknologi MARA, Malaysia
}

\begin{tabular}{l} 
Article Info \\
\hline Article history: \\
Received Sep 15, 2018 \\
Revised Nov 20, 2018 \\
Accepted Dec 13, 2018 \\
\hline
\end{tabular}

\section{Keywords:}

Ease of use

Online learning

Usefulness of online learning

Conducive environment

Virtual learning environment

(VLE)

\begin{abstract}
This paper presents the effectiveness of the Frog VLE implementation from students' perspectives. Virtual Learning Environment (VLEs) is an online systems supporting interactions between and amongst learners and teachers in school. The Frog VLE is a web-based learning system that replicates real life learning by incorporating virtual learning equivalent of traditional concepts of education with the aim to enhance the learning experience beyond the bounded classroom background. Previous studies have identified some difficulties in the Frog VLE implementation such as competency of the teachers and student, facilities and infrastructure of implementing the Frog VLE in school. Therefore, the aim of this study is to measure the effectiveness of the Frog VLE implementation from student perspective as VLE platform may lead to the performance improvement among the students. A survey was conducted with 315 participants, consists of Year 4 and Year 5 primary school students in Shah Alam. The result of the study shows that from the "nature of student self, teacher's competency, useful and ease of use of the application, and conducive learning environment have improve students' academic performance and motivation.
\end{abstract}

Copyright () 2019 Institute of Advanced Engineering and Science. All rights reserved.

\section{Corresponding Author:}

Rogayah Abdul Majid

Faculty of Computing and Mathematical Sciences

Universiti Teknologi MARA,

40450 Shah Alam, Selangor, Malaysia.

rogayah@tmsk.uitm.edu.my

\section{INTRODUCTION}

E-Learning has arise with the utilization of telecom technology to deliver information for education and training. E-Learning is essentially a web-based system that makes information or knowledge can be easily accessed by users and regardless time restrictions or geographic proximity. According to Ahmed, Zakaria \& Elmi (2012), e-learning is an efficient and effective method of learning same as conventional teaching, but it is not substituted of lectures, it simply improves the learning process [1].

The Recent Malaysia Government initiative has introduced Frog Virtual Learning Environment (Frog VLE) to establish a simpler life for teachers and students while enhancing the teaching and learning process. The Frog VLE is a web-based learning system that replicates real life learning by incorporating virtual equivalents of traditional concepts of education [2]. This online learning management system has been launched to enlarge the learning experiences beyond the bounded classroom background. In addition, the Frog VLE also caters searchable lecture materials, forums, streamed video and assessment as learning and teaching resource. A virtual learning environment or VLE is an online education platform which allows teaching and learning between teachers and students via online. Besides enabling students to access information at anytime and anywhere, Frog VLE provides features such as forum and Wikis which allows the student to communicate with their friends and teachers [5]. Frog VLE allows teachers to upload lesson material on the 
VLE in the form of electronic files. On the other hand, the students can upload their homework to the VLE to be assessed by their teacher.

The learning experience through Frog VLE encourages and benefits the students towards positive learning experience is very important and powerful in engaging learners either traditional or online [3]. The Frog VLE provides a social dimension of learning that characterized the classroom practice which provides experience of learning in two environments such as at home and school. Through Frog VLE, learning can be done at any place and any time. With minimum technical skills required to develop a website, teachers or students can employ video, image and educational resources, then arrange and coordinate them in a website [4]. Furthermore, teachers are able to plan and produce their own teaching and learning materials to accommodate the variety of learning techniques.

VLE also contributes to school effectiveness through increasing of the knowledge managements and improvement in skill for knowledge seeking activities. According to Nguyen (2011), the students have to go through VLE based on their own orientation due to unique method of delivery and the class setting [8]. This is due to distance learning via VLE has no face to face communication. Berry (2006) in his study stated that the student will be more confident in giving their thoughts and ideas to classroom discussions as well as in the discussion forum if they get the knowledge on their own [9]. On the other hand, Frog VLE also gives a good impact on students' motivation [19] and learning habit. This was supported by Barker \& Gossman (2013) by stated that the Frog VLEs is able to improve in the learning process and motivate students to learn [11]. This has become an encouragement to the teachers to use the Frog VLE in their teaching.

Previous studies have identified some difficulties in the Frog VLE implementation. A study conducted by Razak and Yusop [4] has identified some difficulties in Frog VLE implementation such as one difficulty that contribute to the ineffectiveness of Frog VLE is the expertise of the academic staff, which focusing on teachers such as additional time needed to react to the forum, some teachers may have problems with lack of free time and technical competency to use the technology. On the other hand, Rashid (2014) stated that, students were not really exposed to the utilization of the Frog VLE platform during teaching and learning session in class [5].

Furthermore, issues related to competency of the teachers and students in using Frog VLE, and infrastructure has led to ineffective implementation of Frog VLE [12]. Since the effectiveness of VLE platform may lead to performance improvement, student perception towards the usage of Frog VLE in increasing their learning performance need to be measured [3][7]. Mohamed (2011) has discovered key elements determining the success of e-learning implementation is the infrastructure such as internet service. Technological designs play an important role in the students' perceived usefulness and eases of use of a course and will has an effect on students' satisfaction [20]. According to Mei et al. (2017), the Frog VLE is a good way to learn, however, it depends on the usability and access to the VLE platform itself [21]. The performance of virtual learning environment can be expanded by allowing a suitable technical support on the current process of virtual learning environment. On the other hand, Staff competency also contributes to the effectiveness of the Frog VLE implementation. Teachers' competency of utilizing the application, ICT devices, employment of the application for teaching and learning are important in the implementation of the Frog VLE [5]. Workshops, seminars and training should be provided to equip staff with the required IT skills such as how to use tools, creating the content and group discussion or forum.

This paper presents the effectiveness of the Frog VLE implementation from students' perspectives. In this study shows that the "nature of student self, teacher's competency, useful and ease of use of the application, and conducive learning environment have improve their academic performance and motivation. However, some of the students have some difficulties to access the application due to several reason. In addition, facilities and infrastructure of the ICT equipment need to be improved in order to increase the effectiveness of the Frog VLE implementation in school. Therefore, the school management plays an importance role to encourage the implemention of the Frog VLE efficiently and successfully.

\section{METHODOLOGY}

A set of questionnaire has been distributed to 315 participants consisting of Year 4 and Year 5 primary students at SK Seksyen 27, Shah Alam. The questionnaire consists of the demographic information involves the age of the respondents, perception towards the Frog VLE implementation effectiveness based on the nature of students' self, the teacher expertise, the usefulness and ease of the application, the existence of conducive environment and the effectiveness of the Frog VLE to improve learning performance. The construction of the questionnaire is based on the research model shown in Figure 1.

The research model of this study is derived from the Technology Acceptance Model (TAM) [2] and Technology Readiness Index (TRI). The TAM model emphasizes on operationalize Behavioral Intension, Perceived Usefulness, and Perceived Ease of Use. Perceived Usefulness was defined as the degree to which a 
person believes that using a particular system would enhance his or her job performance. Perceived Ease of Use referred to the degree to which a person believes that using a particular system would be free of effort. However, TAM does not emphasize on people's tendency to use technology.

The Technology Readiness Index (TRI) consists of four dimensions, namely optimism, innovativeness, discomfort and insecurity [17]. TRI emphasize on people's tendency to use new technologies for accomplishing their task at home life or workplace. Optimism is referring to a positive view of technology, which belief in increased control, flexibility, and efficiency in life due to technology. Innovativeness is a tendency to be the first using a new technology. Insecurity is distrusting of technology and skepticism about its ability to work properly. Discomfort is referring to a perception of lack of control over technology and a feeling of being overwhelmed by it.

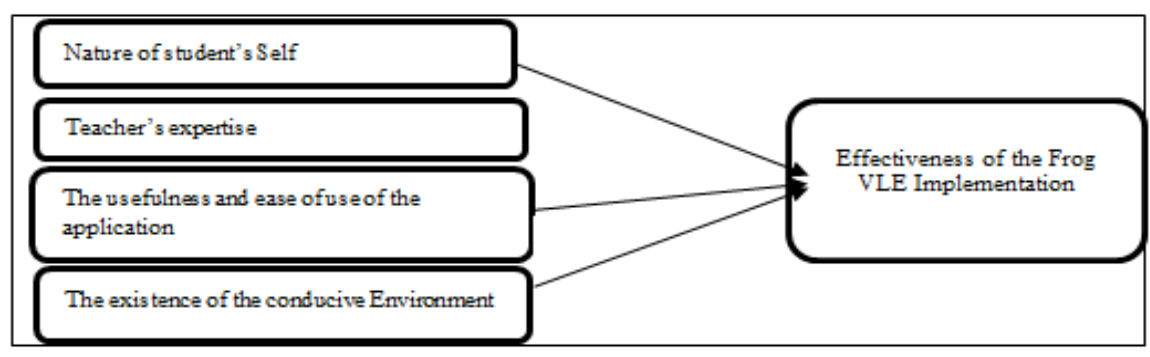

Figure 1. The Research model

The proposed research model consists of two main components that is (1) Independent Variables and (2) Dependent Variable. The independent variables were defined based on the four factors that may affect the implementation of Frog VLE such as the nature of student's self, the teacher's expertise, usefulness and ease of use of the Frog VLE and the existence of conducive environment which have significant impacts undergoing the learning via the Frog VLE. The nature of student's self is important due to measure students intention to use the portal [16][18][20]. On the other hand, teacher expertise is to evaluate teacher competency in using the Frog VLE in teaching and learning [1]. The usefulness and ease of use of the Frog VLE is to evaluate the functionality and features of the Frog VLE to facilitate users [12][17][18][28]. The existence of a conducive learning environment is referring to a complete ICT environment using the ICT rooms or computer laboratories that equipped with the ICT facilities where teaching and learning through the Frog VLE can be carried out successfully [23].

\section{RESULTS AND DISCUSSION}

This section discusses the result of the study on students' perception toward the Frog VLE implementation in school based on factors such as the nature of student self, the teacher's expertise, the usefulness and ease of use of the application, the existence of conducive learning environment.

\subsection{Nature of Student Self}

Result in Table 1 illustrates the nature of student towards the Forg VLE.

Table 1. Nature of Student Self

\begin{tabular}{clc}
\hline No & \multicolumn{1}{c}{ Questions } & Agree \\
\hline 1. & I know and love using Frog VLE & $68.8 \%$ \\
2. & I know how to edit My Dashboard & $62.5 \%$ \\
3. & Learning through Frog VLE is very interesting & $74.4 \%$ \\
4. & Frog VLE has increased my collaboration with my friends and teachers. & $74.3 \%$ \\
5. & After learning through the Frog VLE, I began to give feedback to the teacher. & $74.7 \%$ \\
6. & Revision at home is better when teachers began to share their learning sites & $72.1 \%$ \\
7. & I complete assignments assigned by the teacher through the Frog VLE & $53.3 \%$ \\
8. & By learning via Frog VLE, I can understand better. & $72.1 \%$ \\
9. & Materials uploaded by teachers are very helpful and increase the level of my understanding. \\
10. & I am not interested to use the Frog VLE because it's not interesting. & $71 \%$ \\
11. & I do not know how to use Frog VLE. & $7.7 \%$ \\
12. & Teaching and learning through Frog VLE was bored. & $3.9 \%$ \\
\hline
\end{tabular}


The result shows that more than $60 \%$ of the student know and love to use Frog VLE, and they know how to edit the Dashboard. $74.4 \%$ agreed that learning through Frog VLE is very interesting and allows them to understand better. This is due to learning process becomes more efficient when the students make their own discovery of the new knowledge rather than they just absorb from what has been taught by the teacher in class. Furthermore, the respondents agreed that learning through frog VLE is very interesting and increase their collaboration with friends and teacher. In addition, 53\% of the respondents able to complete their assignments assigned by the teacher through the Frog VLE since the materials uploaded by teachers are very helpful and increase the level of understanding. Furthermore, $72.1 \%$ agreed that the Frog VLE has allowed them to do revision at home since the teacher share assignment through the website. They will get the feedback from the teacher through online.

\subsection{The Teacher's Expertise}

Result in Table 2 illustrates the student perception toward Frog VLE implementation based on their teacher's expertise in handling Frog VLE. The purpose of this survey is to find out the teacher's skill and expertise to operate and manage the Frog VLE during their teaching and learning session.

Table 2. Teacher's Expertise

\begin{tabular}{clc}
\hline No & & \multicolumn{1}{c}{ Questions } \\
\hline 1 & My teacher using a Frog VLE in teaching & $85.9 \%$ \\
2 & My interest towards learning has increased when teachers regularly use Frog VLE. & $66.1 \%$ \\
3. & Assignments assigned by teachers have increased my confidence level. & $69.9 \%$ \\
4 & Teachers always encouraged me to access their learning sites. & $64.5 \%$ \\
5 & Through the Frog VLE, teachers can interact with me and my friends after school or at home. & $69.4 \%$ \\
6. & Teacher comments on my assignments in the Frog VLE have increased my motivation in & $66.2 \%$ \\
& learning. & $8.9 \%$ \\
7 & There are few teachers who are not able to teach me on how to use the Frog VLE because he or & \\
& she was not an expert. & $21.4 \%$ \\
8 & My teachers seldom used Frog VLE in her/his teaching. & $15.5 \%$ \\
9 & Materials uploaded by my teacher are not interesting at all. & $65.8 \%$ \\
10 & Overall, teaching is more effective to use Frog VLE compared to traditional classroom methods.
\end{tabular}

$66 \%$ of the respondents agreed that their interest towards learning has increased since the teacher use frog VLE. This is due to teaching and learning through Frog VLE use an interactive learning. The functions offered in Frog VLE allow the teacher and pupils to upload videos, slide, audio, picture, song, animations and so on. In addition, there are other interactive features such as a forum that allows teacher and students interacts with each other, quiz and assignments for teachers to assign tasks to the pupils and many more.

69.9\% agreed that the Assignments assigned by teachers have increased their confidence level and the teacher always encourages students to access their learning site. $69.4 \%$ agreed teachers can interact with them after school or at home through the Frog VLE. In addition, teacher comments on their assignments in the Frog VLE have increased their motivation in study. $66.2 \%$ agreed that teacher comments on their assignments in the Frog VLE have increased my motivation in learning. It shows that the teacher has knowledge and skill in using frog VLE. Without knowledge and skill it can be difficult for the teacher to use the Frog VLE.

In general, the students were so eager and passionate to learn through the Frog VLE as they believe that Frog VLE has offered a different way of learning compared to traditional learning. Furthermore, students also agreed that learning through the Frog VLE have improve their grade and learning performance.

\subsection{The Usefulness and Ease of Use of the Application}

The Usefulness and Ease of Use of the Frog VLE is measured in term of accessibility, functionality and user friendliness of the Frog VLE from student perspectives.

In term of accessibility, the result in Table 3 shows that $59.9 \%$ of the respondents have agreed that Frog VLE portal can be accessed anytime and anywhere whereby $73.4 \%$ respondents has agreed that the material in the teachers' site can be accessed and downloaded at any time and wherever they want. $66.1 \%$ respondents were saying that internet connection facilities in schools are relatively stable to allow them to use Frog VLE. However, there are $39.3 \%$ of the respondents were saying that sometimes they cannot login to the portal due to slow internet connection. The school management has a responsibility to improve ICT infrastructure at the school, so that they can apply and use the Frog VLE successfully in school. 
Table 3. Usefulness and Ease of Use of Frog VLE

\begin{tabular}{clc}
\hline No & & Questions \\
\hline 1 & The Frog VLE portal can be accessed anytime and anywhere & $59.9 \%$ \\
2 & The material in the teachers' site can be accessed and downloaded at any time and wherever I want. & $73.4 \%$ \\
3 & Internet connection facilities in schools are relatively stable to allow me to use Frog VLE & $66.1 \%$ \\
4 & The functions available in Frog VLE are easy to use and understand. & $70.1 \%$ \\
5 & I can interact with teachers and friends quickly and effectively through the Forum in Frog VLE. & $74 \%$ \\
6. & Through the Frog VLE, textbooks can be viewed digitally. & $59.2 \%$ \\
7 & Through the Frog VLE, I was reminded by Yes Mail about deadlines to submit assignments or & $62.6 \%$ \\
& quizzes given by my teacher. & $75.3 \%$ \\
8 & All school activities have been announced through School Dashboard and Calendar. & $62.8 \%$ \\
9 & Overall, thefeatures of Frog VLE quite easy to use. & $39.3 \%$ \\
10 & Sometimes I cannot log in to the portal due to slow internet connectivity & $40.2 \%$ \\
11. & I did not know some other features in Frog VLE. & $30.5 \%$ \\
12 & I do not like to explore and use Fog VLE &
\end{tabular}

In term of functionality, $70.1 \%$ agreed that the functions available in the Frog VLE are easy to use and understand. $74 \%$ agreed that they can interact with teachers and friends quickly and effectively through the Forum in Frog VLE. Furthermore, through the Frog VLE, textbooks can be viewed digitally. On the other hand, $75.3 \%$ of the respondents preferred to use school dashboard and calendar as a medium that allowed them to keep updated with all of the school activities. However, $40.2 \%$ of the respondents have also mentioned that they did not know any other features in Frog VLE. This is due to less exposure by teachers or the students who did not take the challenge to explore the portal or learn new things.

In term of usefulness and ease of use, $70 \%$ of the respondents found it is easy to use and understand. In Frog VLE, respondents have found that there are functions which are very useful and easy to be used such as forum, whereas $74 \%$ of them agreed that through the forum they are able to interact with teachers and friends quickly and effectively. 62.6\% agreed through the "Yes Mail function", they will reminded about the deadlines of their assignments or quizzes given by my teachers. $62.8 \%$ of the respondents agreed that overall of Frog VLE features quite easy to use and understand.

\subsection{The Existence Of Conducive Learning Environment}

This section discusses on student perceptions towards the Frog VLE implementation based on the existence of conducive learning environment. One of the major factors to measure how successful is the Frog VLE implementation is to measure the facility offered in schools to accommodate the students.

Result in the Table 4 shows that $68.2 \%$ of the respondents agreed that their school is fully equipped with computer facilities to enable students to access the Frog VLE and 62.2\% of them always get the chance to use a computer to access the Frog VLE. However, $26.2 \%$ of the respondents felt very disappointed as sometimes they did not get a chance to log in to the Frog VLE portal at home. This is due to the control by parents when they try to use the portal at home. The parents control the dstudent to access to because that pupils can easily influenced by the negative things that can be accessed through Frog VLE such as unfiltered images as well as indecent videos that can be displayed through YouTube.

Table 4. The Existence of Conducive Learning Environment

\begin{tabular}{|c|c|c|}
\hline No & Questions & Agree \\
\hline 1 & The school is fully equipped with computer facilities to enable students to access the Frog VLE & $68.2 \%$ \\
\hline 2 & I always get the chance to use a computer to Frog VLE & $62.2 \%$ \\
\hline 3 & $\begin{array}{l}\text { In the computer lab, the environment is more conducive to carrying out teaching using Frog VLE when } \\
\text { compared to the class }\end{array}$ & $69.8 \%$ \\
\hline 4 & The school administration has been conducting a campaign to increase the use Frog VLE among students. & $75 \%$ \\
\hline 5 & In addition to the computer lab, there are few places in schools that can be used to access the Frog VLE. & $60.5 \%$ \\
\hline 6 & Sometimes I did not get any chance to $\log$ in to Frog VLE portal. & $26.2 \%$ \\
\hline
\end{tabular}

$69.8 \%$ of the respondents believed that the environment in the computer laboratory is more conducive to carrying out teaching using the Frog VLE compared to the classroom. This is because computer laboratory has been equipted with ICT facilities such as a desktop with internet connection, LCD projector and also WIFI connection which is not avaialable in the classroom. Besides computer laboratory, $60.5 \%$ of the respondents said that they can access to the Frog VLE at the library. In addition, campaign has been organized by the school management in order to create awareness among student and $75 \%$ of the respondents agreed that the campaign has increase the use of the Frog VLE among students. 


\subsection{The Effectiveness Of Frog VLE To Improve The Learning Performance}

Table 5 illustrates the result of student perceptions towards the Frog VLE implementation based on the effectiveness of the Frog VLE to improve learning performance.

Table 5. The Effectiveness of Frog VLE to Improve Learning Performace

\begin{tabular}{clc}
\hline No & \multicolumn{1}{c}{ Questions } & Agree \\
\hline 1 & When teachers start using Frog VLE in teaching them, I have increased the level of understanding. & $67.7 \%$ \\
2 & My revision activities at home become more attractive through the Frog VLE. & $68.4 \%$ \\
3 & Through video and slides uploaded by teachers in their learning sites, the content can be understood & $75.7 \%$ \\
& & \\
4 & more easily. & $60.5 \%$ \\
5 & After learning via VLE Frog, my grades have improved & $73.4 \%$ \\
6 & Overning through Frog VLE has boosted my confidence to succeed & $73.3 \%$ \\
7 & I believe I can be better, if learning via VLE Frog continued. & $79.2 \%$ \\
8 & I did not believe that Frog VLE can improve my grade and learning performance. & $13.7 \%$ \\
9 & I think that teaching and learning through Frog VLE is just wasting my time & $9.5 \%$ \\
\hline
\end{tabular}

The result in Table 5 shows that $67.7 \%$ of the respondents agreed that learning through Frog VLE has increased the level of their understanding. $68.4 \%$ of the respondents mentioned that their revision activities at home become more attractive and interesting when they started using Frog VLE. In addition, $75.7 \%$ of the respondents found that the content can be understood more easily through video and slides uploaded by teachers in their learning sites. This is due to the student like to explore in order to get a better understanding of any information that they want to know. They will search for the informations through YouTube, video, slides and others.

Furthermore, $60.5 \%$ of the respondents found that their grade has been improved after they learn via Frog VLE and $73.4 \%$ agreed that their academic performance is better since the use the Frog VLE. Moreover, $79.2 \%$ of them agreed that they can be better, if learning via VLE Frog continued. Furthermore, $86.3 \%$ believe that Frog VLE can improve their grade and learning performance. However, only $13.7 \%$ of respondents did not believe that Frog VLE can improve their grade and learning performance. In addition, 90.54\% of the respondents also denied that teaching and learning through Frog VLE is just wasting my time.

\section{CONCLUSION}

This paper has presented the effectiveness of the Frog VLE implementation from students' perspectives. This paper has highlighted that the Frog VLE implementation is importance to provide teaching and learning experience to the teachers and students while enhancing the teaching and learning process. The five factors that influence the Frog VLE implementation effectiveness has been identified. The students' perception towards the Frog VLE implementation effectiveness showed that the factors such as the nature of student self, the teacher expertise, the usefulness and ease of use of the application, and the existence of the conducive environment gave a big impact to the implementation of the Frog VLE. The Frog VLE implementation based on the nature of student self and the teacher expertise needs to be improved in order to increase the effectiveness of the application and competency of the teachers. In addition, facilities and infrastructure of the ICT equipment need to be improved in order to increase the effectiveness of the Frog VLE implementation in school. Therefore, the school management plays an importance role to equipt the school with a good infrastructure and facilties in order implement the Frog VLE effiently and successfully.

\section{REFERENCES}

[1] Ahmed A. A, Zakaria N. H., Elmi A. H. An Evaluation Of Virtual Learning Environment Readiness In Higher Education Institutions (Heis ). Journal Of Information Systems Research And Innovation, 2012. 2, 86-94.

[2] Kamalludeen R., Hassan, A., Ahmad Nasaruddin N. S. Student usage patterns of VLE-Frog. Journal of Personalized Learning, 2016, 2(1): 93-101.

[3] Redzuan, F, Lokma, A. M., Othman Z.A., Abdullah, S. 2011. Kansei Design Model for E-Learning: A Preliminary Finding. Proceeding of the 10th European Conference on e- Learning (ECEL-2011), 2011. Pg 685-696. ISBN: 9781-908272-23-2. Index: ISI Thompson, EBSCOHOST.

[4] Razak R. A. Yusop F. Designing Framework Of Electronic Continued Professional Development For Teachers (E$C p d)$. The Annual International Conference On Management And Technology In Knowledge, Service, Tourism \& Hospitality, 2013.

[5] Rashid A. H. A. Teachers' Perception Towards Virtual Learning Environment. Psychological Science. Thesis Report. Universiti Teknologi Malaysia. 2014. 
[6] Harun H, Esa A, Amiruddin M. H., Masek A, Samad, N. A., Noor S., Noor F. M., Kamarudin M. H. Utilization of FROG VLE as Teaching Tools: Readiness of Islamic Education Teachers in Muar District Schools. American Scientific Publishers, 2016. Available from: https://www.researchgate.net/publication/313565857

[7] Stricker D, Weibel D, Wissmath B. Computers \& Education Ef Fi Cient Learning Using A Virtual Learning Environment In A University Class. Computers \& Education, 2011. 56(2), 495-504.

[8] Nguyen D. D,. An Empirical Study Of Student Attitudes Toward Acceptance Of Online Instruction And Distance Learning, 2011. Journal on The Contemporary Issues in Education Research, 4(11). 23-38.

[9] Berry R. A. W. Inclusion, Power, and Community:Teachers and Students Interpret the Language of Community in an Inclusion Classroom. American Educational Research Journal, 20016, vol. 43, 3: pp. 489-529.

[10] Salleh M. F. M. E-Learning Issues in Malaysian Higher Education. Penerbit UTM Press. 2008. ISBN: 978-983-520560-6.

[11] Barker J, Gossman P. The Learning Impact Of A Virtual Learning Environment: Students' Views. Teacher Education Advancement Network Journal (TEAN), 2013, 5 (2). pp. 19-38.

[12] Mohamed M. A . Penggunaan Sistem E-Learning Di Fakulti Pendidikan Universiti Teknologi Malaysia. Thesis Report. Fakulti Pendidikan Universiti Teknologi Malaysia, 2011.

[13] Ali W, G. M. Factors Affecting Nursing Student's Satisfaction with E- Learning Experience in King Khalid University, Saudi Arabia. International Journal of Learning \& Development. 2012, Vol. 2, No. 2.

[14] Abuhlfaia K, Quincey E. D. The Usability of E-learning Platforms in Higher Education: A Systematic Mapping Study. Proceedings of British HCI 2018.

[15] Huertas A. Teaching and Learning Logic in a Virtual Learning Environment. Logic Journal of the IGPL. 2007 , Vol. 15, pp. 321-331.

[16] Ahmed A. A., Zakaria N. H., Elmi A. H. An Evaluation Of Virtual Learning Environment Readiness In Higher Education Institutions (Heis). Journal Of Information Systems Research And Innovation, 2012. Vol. 2, 86-94.

[17] Larasati N, Santosa P. I. Technology readiness and technology acceptance model in new technology implementation process in low technology SMEs. International Journal of Innovation, Management and Technology. 2017, Vol 8 (2), pp. 113.

[18] Said M. N. H. M., Krishnan J. Faktor-faktor yang mempengaruhi penggunaan e-pembelajaran di kalangan pelajar tahun akhir Jabatan Multimedia (SPK, SPT, dan SPP) Fakulti Pendidikan, Universiti Teknologi Malaysia. Journal of Social Science, 2011, Vol 3, Pp 206

[19] Liaw S. S. Investigating Students' Perceived Satisfaction, Behavioral Intention, And Effectiveness Of E-Learning: A Case Study Of The Blackboard System. Journal of Computers And Education, 2008, 51(2), pp. 864-873.

[20] Sun P.C., Tsai R. J., Finger G., Chen Y.Y., Yeh D. 2008. What Drives A Successful E-Learning? An Empirical Investigation Of The Critical Factors Influencing Learner Satisfaction. Computers \& Education, 50(4), 1183-1202.

[21] Mei L. M., Su L. W., Ayub A. F., Mahmud R. 2017. Teachers' Perceptions of E-Learning in Malaysian Secondary Schools. Malaysian Online Journal of Educational Technology. Vol.5 (2), Pp. 20 - 33. 